\title{
SISTEM EKONOMI LAISSEZ FAIRE PEMIKIRAN ADAM SMITH
}

\author{
RISKAYANTI.M
}

90100118027

A Pengertian Laissez Faire

Laissez-faire berasal dari bahasa Perancis yang berarti "biarkan terjadi" (secara harafiah "biarkan berbuat"). Istilah ini bersumber dari diksi Perancis yang dipergunakan pertama kali oleh para psiokrat pada ratus tahun ke 18 sebagai wujud perlawanan terhadap intervensi pemerintah dalam perdagangan. Gaya kepemimpinan laisserfaire (bebas), dimana Gaya kepemimpinan ini pada dasarnya berpandangan bahwa anggota organisasi mampu mandiri dalam membuat keputusan atau mampu mengurus dirinya masing-masing, dengan sedikit mungkin pengarahan atau pemberian petunjuk dalam merealisasikan tugas pokok masingmasing sebagai bagian dari tugas pokok organisasi. Istilah laissez-faire sering dipergunakan bergantian dengan istilah "pasar bebas sama sekali". Beberapa mempergunakan laissez-faire kepada merujuk pada perilaku "biarkan terjadi, biarkan lewat" dalam hal-hal di luar ilmu ekonomi. Pandangan laissez-faire, kewajiban negara bukanlah melakukan intervensi kepada menstabilkan distribusi kekayaan atau kepada menjadikan sebuah negara makmur kepada melindungi rakyatnya dari kemiskinan, melainkan bersandar pada sumbangan dan sistem pasar.

B Pemikiran-Pemikiran Adam Smith

Beberapa pemikiran Adam Smith yang dikemukakannya antara lain:

1) Smith berpendapat bahwa pemerintah tidak boleh terlalu mengintervensi pasar, dan mendukung campur tangan seminimal mungkin dari pemerintah dalam perekonomian, dan berpendapat 
bahwa Invisible Hand yang dapat membawa keseimbangan pada perekonomian.

2) Adam Smith berpendapat bahwa diharuskan adanya pembagian spesialisasi atau pembagian kerja agar terjadi produktivitas kerja. Smith mempercayai bahwa peningkatan output akan bertambah dengan adanya pertambahan penduduk yang disertai dengan perluasan pembagan kerja.

3) Mendukung adanya perdagangan bebas anatar negara karena akan menurunkan biaya produksi barang ekspor karena perusahaan bisa mendapatkan barang yang lebih murah dari luar negeri. Smith menentang proteksi bagi Industri karena akan memunculkan monopoli, dan monopoli ini buruk bagi perdagangan bebas karena dapat menghambat pertumbuhan ekonomi.

4) Menolak kekuatan monopoli yang dapat merusak pasar, Smith mendorong penggunaan harga natural dari persaingan bebas dari pada adanya monopoli. Dia juga menolak pemberian hak istimewa terhadap perusahaan tertentu.

5) Memberlakukan sistem pajak guna membiayai pengeluaran publik, namun pajak ini musti proporsional.

6) Dibutuhkannya akumulasi capital melalui penghematan dan investasi modal yang berperan sebagai faktor penting dalam pertumbuhan ekonomi.

7) Tingkat upah yang lebih tinggi dari pada tingkat upah subsisten akan meningkat beriringan dengan jumlah penduduk, namun jumlah penduduk akan tetap jika upah subsistennya stasioner.

C Ide - Ide Dasar Laissez Faire

Adapun ide dasar laissez faire antara lain :

1) Perekonomian berjalan berdasarkan penawaran dan permintaan

2) Perekonomian harus bebas dari intervensi penguasa/ pemerintah.

3) Kepunyaan pribadi atas sumber daya dan kebabasan dalam mengelolanya dalam artian perekonomian oleh perusahaan swasta. 
4) Pemerintah hanya bertugas untuk memastikan bahwa sistem dan mekanisme pasar bekerja, hal ini diwujudkan dalam penegakan hal milik property.

5) Perdagangan iternasional terjadi secara bebas (perdagangan bebas internasional akan mendatangkan kemakmuran dan alokasi sumber daya yang lebih efisien. 


\section{DAFTAR PUSTAKA}

1) Hastarini Dwi Atmanti, "Kajian Teori Pemikiran Ekonomi Mazhab Klasik dan Relevansinya pada Perekonomian Indonesia”, Jurnal Ekonomi \& Bisnis, Volume 2, Nomor 2, September 2017, hal. $512-513$

2) Cerdasco. Laissez Faire: Konsep, Ide Dasar, Kelebihan dan Kekurangan. https://cerdasco.com/laissez-faire/ (diakses pada 21 April 2021)

3) Anggreta. 2019. "The Impact of Laissez Faire Leadership Style and Communication on Employee Performance at Retail Companies in Sidoarjo, Indonesia." Indonesian Journal of Law and Economics, 